\title{
Organizational Environment, Personal Resources and Work Engagement as Predictors of Coaching Performance
}

\author{
Bas Kodden \\ Nyenrode Business University \\ Leon Hupkes \\ Nyenrode Business University
}

We developed and tested a model examining the influence of organizational environment, job demands, personal resources, burnout and work engagement on the coaching performance of coaching professionals. The study proposed that there is a relationship between organizational environment and coaching performance and that personal resources and work engagement mediate the effects of this relationship. The study implies that both the health impairment and motivational processes as described by the JDR-model can be applied to the context of coaching professionals. Because of the strategic importance of human capital in coaching enterprises, it is important for the continuity of the organization that they will provide their practioners with tangible suggestions to improve coaching performance.

Keywords: Organizational environment; job demands; personal resources; J-DR theory; burnout, work engagement; coaching performance.

\section{INTRODUCTION}

Competition is strong in the coaching market (Schats, 2011). The title of coach is not protected in many western countries, which allows anyone to compete on the market. This creates the urgency for coaching businesses to adopt new strategies to retain market share. The challenge for managers of coaching businesses is to remain competitive to overcome market pressures. It is important for coaching businesses to employ effective coaches that deliver qualitative coaching to customers as this is the primary way in which coaching businesses create value for their customers. When the demands on employees are too high for a sustained period, employees can become exhausted and develop a cynical attitude towards work if the employees do not have access to sufficient resources to recuperate from the sustained demand (Schaufeli \& Bakker, 2004). Prolonged exhaustion can eventually lead to the development of burnout (Maslach, Schaufeli \& Leiter, 2001). In contrast, when employees work in an organizational environment that is rich in job resources like autonomy, a healthy work-life balance and receiving sufficient feedback that nourishes the reciprocal employer-employee relationship, an employee can become engaged at work (Schaufeli \& Bakker, 2004). What enables coaches to utilize their skills and talent to their fullest potential to enable coaching business to provide competitive coaching services? To answer this question, this study investigates different determinants of coaching performance. The 
objectives of this study are to identify the extent to which organizational and personal resources play a role in coaching performance outcomes, to identify the extent to which mental well-being, in the form of burnout and engagement, plays a role in the organization-performance and the person-performance relationship and to present coaching businesses with empirical findings that provide tangible input for organizational practice.

\section{THEORY AND HYPOTHESES}

\section{Coaching Performance}

This study focuses on the role of the coaching professional as the primary value driver for the coaching business. The coaching professional creates this value by helping coachees and their employers, to achieve goals specific to the wishes of either the coachee or the employer (Theeboom et al., 2014; Jones et al., 2015; Grover \& Furnham, 2016). To provide an overview of all the qualities that illustrate the performance of coaching professions, Lai and McDowall (2014) conducted a systematic review of studies focused on wide range of attributes of coaching psychologists to summarize the available evidence base. They conclude that coaching competency is built up of a wide array of factors like required knowledge, personality, attitudes, skills and behaviors which are summarized in the study in a coaching competency framework (Lai \& McDowall, 2014). The five factors that are consistent predictors of coaching performance are (1) building trust, (2) handling the coachee's emotional challenges, (3) maintaining a two-way conversation with the coachee, (4) facilitating the coachee's development and learning process and (5) maintaining transparency throughout the entire coaching trajectory (Lai \& McDowall, 2014). These performance indicators follow what Goodman and Syvantek (1999) define as task performance, or what is commonly known as in-role performance. Any activities that are performed on the job that are not within the given tasks of the function are defined as extra-role behaviors. Previous investigations into role-performance point to a diverse relationship between mental well-being and role-performance. A meta-analysis by Taris (2006) shows a high correlation between exhaustion and in-role performance. The relationship between engagement and role- performance has been replicated in several studies (Xanthopoulou, Bakker, Demerouti, \& Schaufeli, 2009a; Demerouti, \& Cropanzano, 2010; Gruman \& Saks, 2011). Halbesleben and Wheeler (2008) show that both self-reported as supervisor-rated in-role performance were predicted by engagement in a longitudinal study. To re-test these findings for coaching, in line with Lai and McDowall's framework (2014), in-role performance will provide the measurement for coaching performance in this study.

\section{Burnout, Job Demands and Coaching Performance}

To understand what makes coaches perform, it is import to look at how coaches manage their energy, because when the demands on the coaches are too high for a sustained period, they can become exhausted and develop a cynical attitude towards work if they do not have access to sufficient resources to recuperate from the sustained demand (Schaufeli \& Bakker, 2004). This prolonged demand can eventually lead to the coaches burning out (Maslach, Schaufeli \& Leiter, 2001). Where does burnout come from? Studies into the determinants and correlates of burnout point to several factors. Neuroticism, anxiety and lack of hardiness are found to be important personality characteristics to indicate an increased risk of burnout (Schaufeli \& Buunk, 2003). In the work environment, workload, time pressure and role conflict have been pointed out as strong predictors where quantitative demands like workload have a stronger relationship with burnout than qualitative demands like emotional labor or dealing with emotionally demanding situations on the job like death and suffering (Schaufeli \& Buunk, 2003). A consistent outcome of individual approaches to burnout is that strong motivation and dedication, underlined by high personal goals, expectations and aspirations are a consistent factor that can lead to the emergence of burnout. In essence, there is a strong motivational and attitudinal component to the onset of burnout. A misperception of reality and consequent expectations can be an important factor driving job stress which over time may lead to burnout; especially combined with a lack of proper coping strategies or other lacking personal and job resources (Schaufeli \& Buunk, 2003). Effect studies that investigate the 
outcomes of burnout interventions generally vary a lot in sample selection, time frame, measurement methodology, and intervention type. This complicates the possibility to draw strong generalized conclusions out of this research body. One general insight that does arise from effect studies is that teaching professionals specific coping skills like relaxation techniques can reduce emotional exhaustion (Schaufeli \& Bakker, 2004). Actively stimulating social support at work does not seem to have a positive effect on burnout, even though it does positively affect work satisfaction (Schaufeli \& Bakker, 2004). The focus of this study is to investigate the role of burnout in the relationship between the organizational environment in the form of job demands and coaching performance. Through investigation previous findings into the health impairment process it is expected that job demands will negatively influence coaching performance and that when burnout is introduced as a mediator, most of this effect will be mediated by burnout. Therefore, the following hypotheses are suggested:

Hypothesis 1: Job demands will be negatively related to coaching performance.

Hypothesis 2: The negative relationship between job demands and coaching performance will be fully mediated by burnout

To contrast this negative effect of burnout we used the empowering effect of engagement.

\section{Engagement and Job Resources as Determinants of Coaching Performance}

In understanding what makes professional coaches perform successfully it is important to investigate what drives coaches to do so; how important is motivation and the level of engagement for professional coaches? From a linguistic perspective, engagement can be viewed as a simply transactional interaction where one is instructed or engaged to perform an activity, or engagement can be perceived as a way to motivate and inspire (Kodden \& Van Ingen, 2019). These two extremes map the spectrum of engagement that one can experience at work. Demerouti et al. (2001) stimulated a paradigm shift on engagement with their research into the potential for stimulation of engagement. As one of the early investigators, Kahn (1990) views engagement as the extent to which employees physically, cognitively and emotionally couple themselves to their job. This coupling refers to being actively present and in the moment when one is engaged, or being passive and withdrawn when disengaged (Kodden \& Van Ingen, 2019). Rothbard (2001) adds to Kahn's (1990) definition of engagement by specifying attention, cognitive availability, and absorption, intensity of focus, as main components to the concept (Blomme \& Kodden, 2014). Rothbard's (2001) definition provided the basis for the current most dominantly used definition of engagement "as a positive, fulfilling, work-related state of mind that is characterized by vigor, dedication, and absorption" (Schaufeli et al., 2002). Examples of vigor are (1) having a lot of energy, (2) having mental resilience at work (3) being willing to invest effort in work, (3) having persistence and resilience when working on difficult tasks at work and (4) having an active, ambitious and driven attitude at work. Absorption refers to (1) a highly concentrated mental state, in which (2) time seems to pass quickly, (3) where it becomes difficult to stop working and (4) the employee feels good about being absorbed at work. Dedication is characterized by (1) a strong sense of meaning making at work, a sense of significance, (2) feeling prideful and enthused about work, (3) cherishing a strong sense of commitment and inspiration from work. Bakker (2009) indicates four factors that explain a performance difference between high- and lowengaged employees. High-engaged employees (1) tend to experience more positive emotions, (2) be more healthy, (3) share their engagement with peers and (4) actively seek out sufficient support of work and personal resources more than low- engaged employees. Kodden (2011) postulates from all dimensions of engagement that dedication is the primary driver of organizational performance. This postulation has been supported by earlier findings (Halbesleben \& Wheeler, 2008). As with burnout; engagement develops though a reciprocal relationship between employer and employee (Kodden \& Roelofs, 2019). When both parties invest time and energy into the relationship; employee engagement can flourish. The Job Demands-Resources (JD-R) model neatly ties together job demands, resources, burnout and engagement and the way in which these factors affect job performance. The JD-R model has gained a lot of traction 
since its introduction in 2001 as a popular approach for both researchers and practitioners (Schaufeli \& Taris, 2014). A major underpinning of the JD-R model is the generalizability of job demands and resources across any occupation, which allows it to function as an overarching model that can be applied to various occupational settings, independent of specific types of job demands, and resources (Bakker, Demerouti, \& Euwema, 2005; Schaufeli \& Bakker, 2004; Demerouti et al, 2001). The original JD-R model was inspired by the demand-control model (Karasek, 1979) and defines factors in the organizational environment that lead to exhaustion and disengagement as either job demands or job resources. Job demands can be defined as "the degree to which the environment contains stimuli that peremptorily require attention and response" (Jones \& Fletcher, 1996), or simply put: work that has to be done. Bakker et al. (2005) elaborate on this definition by additional classification. In their definition, job demands are "negatively valued physical, social, or organizational aspects of the job that require sustained physical or mental effort and are therefore associated with certain physiological and psychological costs" (Schaufeli \& Taris, 2014; Bakker et al., 2005). Job demands don't have a negative influence on psychological well- being by default. They could turn into stressors when high effort is required in meeting the required demands (Schaufeli \& Bakker, 2004). In such a case high effort can lead to high costs in psychological health that can lead to negative outcomes like anxiety, depression or burnout (Schaufeli \& Bakker, 2004). Both quantitative (workload, mental demands) as qualitative (emotional demands) job demands are included in this study. Job resources are positive factors in the work environment that can be defined as "positively valued physical, psychological, social, or organizational aspects of the job that (1) are functional in achieving work goals, (2) reduce job demands and the associated physiological and psychological costs, and (3) stimulate personal growth and development" (Schaufeli \& Taris, 2014; Bakker et al., 2005). In addition, Hobfoll (2002) concludes that higher resource levels tend to be favorable, especially in situations of high-stress, and that higher resource levels are connected with higher performance and goal-oriented behavior. In a 2004 study Schaufeli \& Bakker elaborate on the original JD- R by expanding the definitions of positive and negative psychological health factors burnout and engagement into the model (see figure 2). This framework provides the basis for this study. It does so by providing a theoretical structure for the organizational environment in the form of job demands and resources, a theoretical structure for psychological well-being in the form of burnout and engagement and finally the relationship with coaching performance as an outcome. Two theoretical assumptions underlying the JD-R model are (1) that job demands play an important role in predicting burnout and (2) that job resources can provide a buffer for the negative effects of job demands. In their extension, Schaufeli and Bakker (2004) describe the JD-R model as a "dual process model". This entails both the health impairment process (energy driven) in which job demands can lead to burnout and consequently health impairment, and the motivational process (motivation driven) in which job resources stimulate employee engagement, which drives positive organizational outcomes like coaching performance.

Hypothesis 3: Job resources will be positively related to coaching performance

Hypothesis 4: The positive relationship between job resources and coaching performance will be fully mediated by engagement.

\section{Personal Resources}

The motivational process in which job resources lead to engagement and increased job performance and the health impairment process in which job demands lead to burnout and decreased job performance are influenced by personal resources (Xanthopoulou et al., 2007). It is therefore important to investigate what insights into personal resources can contribute to the understanding of the relationship between the organizational environment and coaching performance. The initial JD-R model provides a framework to structure the relationship between the organizational environment, the states of burnout and engagement and organizational outcomes. An important addition to this model is the inclusion of personal resources as most psychological approaches tend to factor in an interaction between the person and the environment to 
predict behavior (Schaufeli \& Taris, 2014); before the inclusion of personal resources, the JD-R model did not investigate the effect of a person-environment interaction to predict well-being and organizational outcomes. The addition of personal resources provides insight into individual differences that affect the way that the health impairment and motivational processes have an effect on organizational outcomes. Personal resources are operationalized as positive self- evaluations that are related to resiliency and a sense of ability to successfully influence the organizational environment (Hobfoll et al., 2003). These self-evaluations are indicators for life satisfaction, motivation, performance and related desirable outcomes (Judge, Vianen \& Pater, 2004). An increase in personal resources positively affects goal selfconcordance, e.g. the pursuit of goals that fit with personal interests, which in turn helps individuals achieve more and make individuals more satisfied about their outcomes at work (Luthans \& Youssef, 2007; Schaufeli \& Taris, 2014). Personal resources, in combination with job resources, can safeguard employees from persistent job strain, which can lead to burnout (Blomme \& Kodden, 2015). Employees who are more effective in exercising their personal resources tend to have more control over their job, which enables them to be more resilient in demanding situations (Hannah, Avolio, Luthans \& Harm, 2008; in Blomme \& Kodden, 2014).

Hypothesis 5: Personal resources will be positively related to coaching performance

Hypothesis 6: The negative relationship between job demands and coaching performance will be fully mediated by personal resources

Hypothesis 7: The positive relationship between job resources and coaching performance will be fully mediated by personal resources

\section{METHOD}

\section{Sample and Procedure}

Our sample consisted of 389 professional career and life coaches. From the coaching population, only people who identify as a professional coach and who work in this profession more than 20 hours per week were included in the study to make sure that the participants in the sample have sufficient experience as a coach and that the work as a professional coach plays a dominant role in the working life of the participant. The population of the 389 respondents represented 187 women (48\%) and 202 men (52\%).

\section{Measures}

Coaching Performance

Coaching performance was measured based on in-role performance ( 5 items, $\alpha=.84$ ) using the scale adapted from Goodman and Svyantek (1999). In-role performance was measured with a five-point scale ranging from "completely disagree" to "completely agree." Example items are "You manage all facets of your job" and "You adequately complete all of your assigned duties".

\section{Job Demands}

Three different job resources have been investigated in this study; workload ( 3 items, $\alpha=.81$ ), emotional demands (5 items, $\alpha=.68$ ) and mental demands (5 items, $\alpha=.74$ ). The scales for these constructs originate from the Questionnaire on the Experience and Evaluation of Work (QEEW), a commonly used questionnaire by researches in the Netherlands (Van Veldhoven, De Jonge, Broersen, Kompier, \& Meijman, 2002) and include questions like "do you have to work very fast? (workload), "do (internal) customers sometimes harass you?" (emotional demands) and "do you have to process big amounts of data?" (mental demands). Each of these constructs were measured on a five-point scale ranging from "never" to "always". 


\section{Burnout}

Burnout was measured using the Maslach Burnout Inventory- General Survey (MBI-GS; Schaufeli et al., 1996), which measures exhaustion (5 items, $\alpha=.90$ ) and cynicism (4 items, $\alpha=.84$ ). The sub-scale professional efficacy was omitted from the study as "accumulating evidence indicates that lack of professional efficacy plays a divergent role" (Schaufeli, Bakker and Rhenen, 2009) in comparison to exhaustion and cynicism which are viewed as the "core" of burnout. Therefore, professional efficacy was not measured in this study. Both exhaustion and cynicism use a seven-point frequency scoring range ranging from "never" to "always".

\section{Engagement}

To measure engagement the Utrecht Work Engagement Scale (UWES-9; Schaufeli et al., 2006b) was used. This scale is comprised of three underlying dimensions, being vigor ( 3 items, $\alpha=.89$ ), dedication (3 items, $\alpha=.95$ ) and absorption ( 3 items, $\alpha=.88$ ). Typical examples of this scale are "I feel fit and strong when I work" (vigor), "I'm proud of my work" (dedication) and "I get carried away when I am working" (absorption). All items on the UWES-9 are measured with seven-point scale ranging from "never" to "always".

\section{Job Resources}

Three different job resources were measured in this study; communication ( 7 items, $\alpha=.70$ ), worklife balance ( 3 items, $\alpha=.73$ ) and feedback ( 3 items, $\alpha=.86$ ). Communication at work was measured with a scale from the VBBA (Veldhoven \& Meijman, 1994). Work-life balance was measured with the work-home interference (WHI) scale (Demerouti, Bakker \& Bulters, 2003). Feedback was measured by a three-item scale, which was developed by Bakker et al. (2003). Both feedback and communication were scored on a scale ranging from five-point scale ranging from "never" to "always". Work- life balance was measured with a five-point scale ranging from "completely disagree" to "completely agree".

\section{Personal Resources}

To measure personal resources, three concepts were measured: self-efficacy (3 items, $\alpha=.77$ ), optimism ( 6 items, $\alpha=.63$ ) and stress-resilience ( 25 items, $\alpha=.90$ ). Self-efficacy was measured with a scale adapted from Schwarzer and Jerusalem (1995). A scale constructed by Scheier, Carver and Bridges (1994) was translated to Dutch to measure optimism in this study. It has to be noted that optimism's reliability alpha is somewhat low (.63). This could be the result of some error in the translation process. This alpha value is still sufficient for use in this study. The third personal resource, stress-resilience, was measured with a 25-item scale from Wagnild (1993). All personal resources were measured with scales ranging from "completely disagree" to "completely agree". Self- efficacy was a six-point scale, optimism a five-point scale and stress resilience a seven- point scale.

\section{Data Analysis}

To test the hypotheses, reliability and factor analyses were performed. To test internal scale consistency Cronbach's alphas were calculated for each of the measured constructs. Two constructs had Cronbach's alphas under 0.70; emotional demands and optimism. Because removing items from these constructs would not improve the Cronbach's alpha, no changes to the scales were made to improve reliability. To evaluate the measurement model, a Conformity Factor Analysis (CFA) was performed. The construct reliability (CR) of all latent variables exceeded the .70 threshold. To ensure minimal effects of common method bias, several steps were taken. First, participants were affirmed of total confidentiality and anonymity and stimulated to respond to the questions as frankly and intuitively as possible. This was done to help lessen any evaluation comprehension and make them less likely to give socially desirable answers and secondly, different types of Likert scales were to help reduce the effects of one type responses. 


\section{RESULTS}

Table 1 displays descriptive statistics, correlations, and coefficient alphas for all factors extracted from the survey data. To provide a general overview of the relationships between the constructs their correlations have been calculated and presented in table 1. Because only job demands is normally distributed, Spearman correlations have been calculated between each of the factors in the conceptual model (Bowerman et al., 2011).

TABLE 1

MEANS, STANDARD DEVIATIONS AND CORRELATIONS (SPEARMAN), $\mathbf{n}=\mathbf{3 8 9}$

\begin{tabular}{|l|l|l|l|l|l|l|l|l|}
\hline & Mean & SD & 1. & 2. & 3. & 4. & 5. & 6. \\
\hline 1. Job Demands & 2.94 & 0.51 & 1 & & & & & \\
\hline 2. Job Resources & 4.11 & 0.56 & $-.44^{* *}$ & 1 & & & & \\
\hline 3. Personal Resources & 0.83 & 0.08 & .03 & $.20^{* *}$ & 1 & & & \\
\hline 4. Burnout & 2.17 & 0.74 & $.33^{* *}$ & $-.44^{* *}$ & $-.49^{* *}$ & 1 & & \\
\hline 5. Engagement & 5.30 & 0.99 & -.02 & $.18^{* *}$ & $.61^{* *}$ & $-.59^{* *}$ & 1 & \\
\hline 6. Coaching Perf. & 4.15 & 0.47 & $.01^{*}$ & $.12^{*}$ & $.52^{* *}$ & $-.37^{* *}$ & $.50^{* *}$ & 1 \\
\hline
\end{tabular}

$* p<.05, * * p<.01$

Table 1 shows that the found correlations are generally in line with the relations expected in the job demands-resources theory. The expected relationships in both the health impairment and motivational are replicated. Job resources correlate positively with engagement $(r=.18, p<.01)$ and likewise job demands correlate positively with burnout $(r=.33, p<.01)$. Cross correlations between the dual processes are found as job demands and job resources correlate negatively $(r=-.44, p<.01)$, as do burnout and engagement $(r$ $=-.59, p<.01)$. None of the correlations exceed the .70 threshold. This indicates that there is no imminent risk of multicollinearity effects when performing regression analyses between the constructs.

The next step is to look with more detail into inter-dependence of the studied concepts by investigating the Spearman correlations on a factor-item level as presented in table 2. 


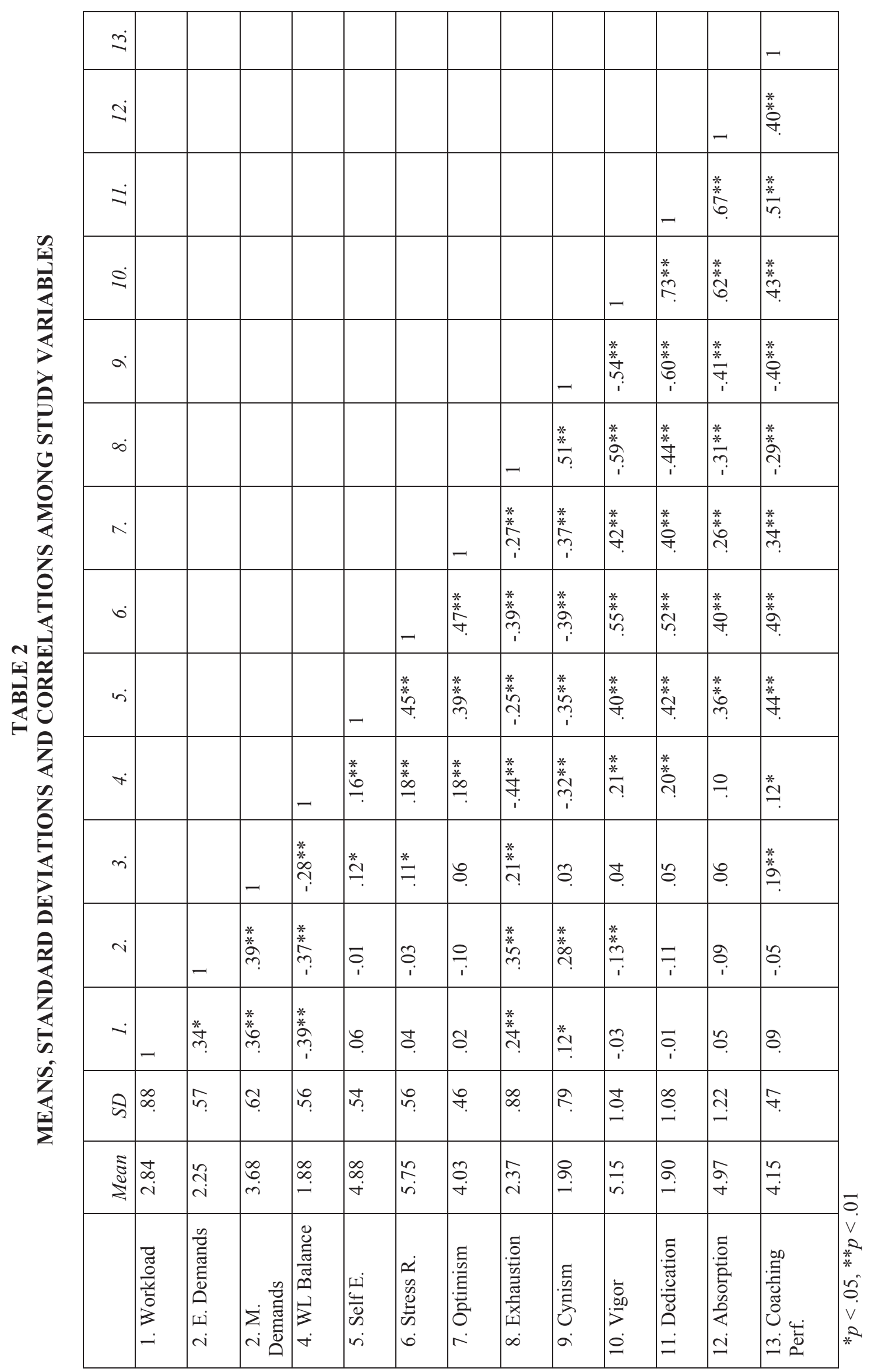

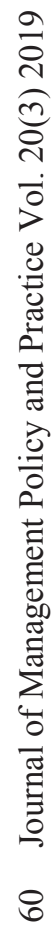


As with the correlations on the conceptual level, the correlation table on the factor-item level shows inter-item dependencies that are generally in line with expectations that stem from the JD-R theory. For example, correlations between the factors that make up job demands are all moderate and significant $(r=$ $.34, p<.01 ; r=.36, p<.01 ; r=.39, p<.01)$. Exhaustion and cynicism, that make up the concept burnout are strongly correlated with each other $(r=.51, p<.01)$. The strongest inter- concept correlations can be found within the dimensions of engagement, where vigor, dedication and absorption correlate highly with each other $(r=.73, p<.01 ; r=.62, p<.01 ; r=.67, p<.01)$. Most importantly, some important expected correlations between in-role performance and the rest of the model can be found in this correlations table. For example, the three dimensions of engagement all positively relate to in-role performance $(r=.43$, $p<.01 ; r=.51, p<.01 ; r=.40, p<.01)$. As the counterpart to engagement, burnout in the form of exhaustion and cynicism correlate negatively with in-role performance $(r=-.29, p<.01 ; r=-.40, p<.01)$. Surprisingly, the job resource work-life balance related negatively with performance $(r=-.12, p<.05)$ the job demand mental demands related positively with in-role performance $(r=.19, p<.01)$. The other job demands, workload and emotional demands, did not correlate significantly with in-role performance.

To test the hypotheses, direct effects between the concepts in the conceptual model have been tested and are presented in figure 1.

\section{FIGURE 1}

\section{DIRECT EFFECTS BETWEEN THE CONCEPTS IN THE CONCEPTUAL MODEL}

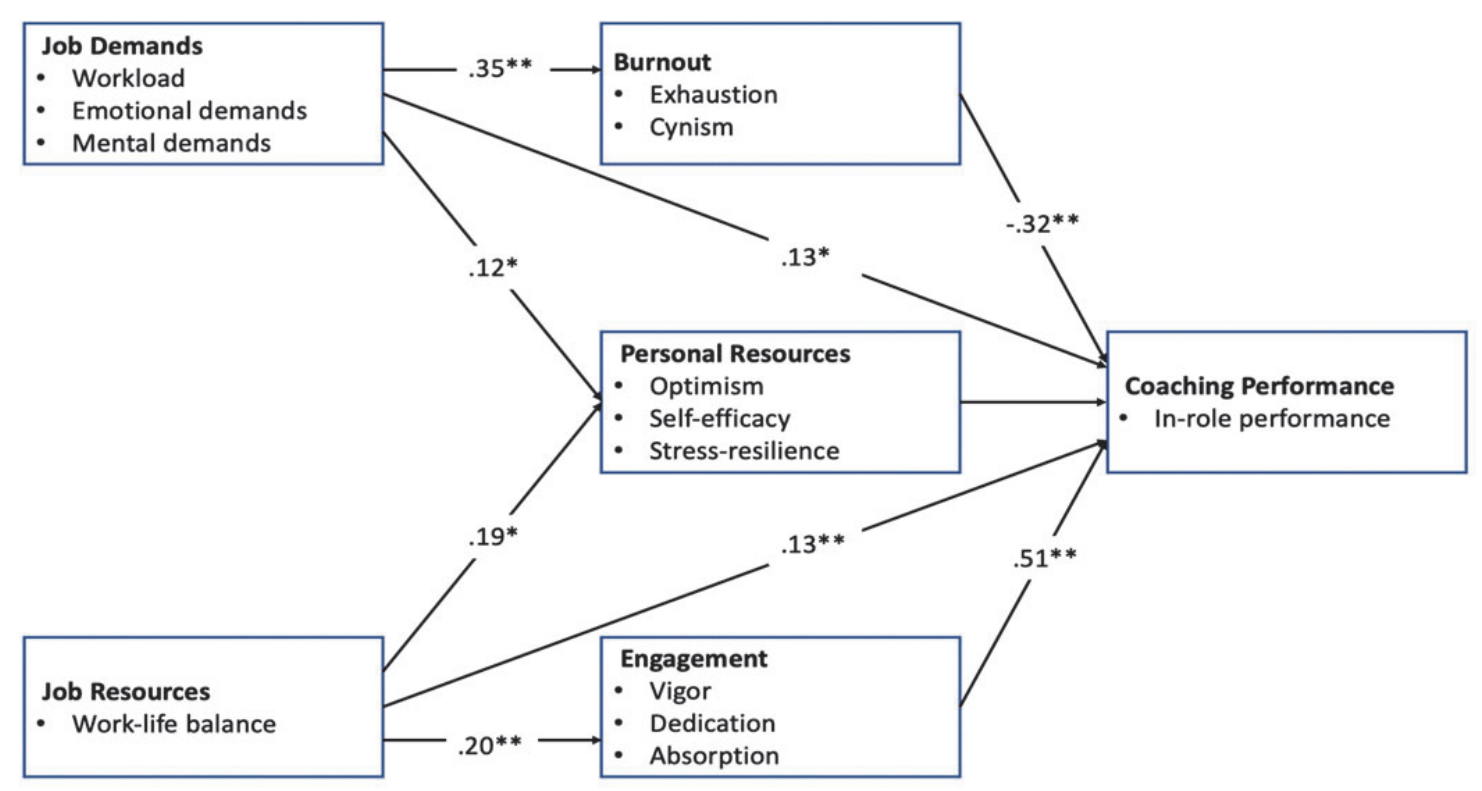

In addition, the regression results for the direct effects are presented in tables 3 and 4. Tolerance and variance inflation factors (VIF) are all within desired parameters for each of the direct-effect regression analyses. 
TABLE 3

BETA, ADJUSTED R SQUARED AND F-STATIC VALUES FOR ALL DIRECT REGRESSIONS BETWEEN CONCEPTS

\begin{tabular}{|l|l|l|l|l|l|l|l|}
\hline & & Dependent & Variables & & & & \\
\hline & Personal & Resources & & & & Burnout & \\
\hline & Beta & Adj. $\mathrm{R}^{2}$ & $\mathrm{~F}$ & & Beta & Adj. $\mathrm{R}^{2}$ & $\mathrm{~F}$ \\
\hline 1. Job Demands & $.12^{*}$ & .01 & 5.62 & & $.35^{* *}$ & .12 & 54.78 \\
\hline 2. Job Resources & $.19^{* *}$ & .03 & 13.72 & & $-.45^{* *}$ & .20 & 99.51 \\
\hline 3. Personal Resources & -- & -- & -- & & $-.39^{* *}$ & .15 & 71.25 \\
\hline 4. Burnout & $-.39^{* *}$ & .15 & 71.25 & & -- & -- & - \\
\hline 5. Engagement & $.63^{*}$ & .39 & 252.43 & & $-.56^{* *}$ & .31 & 176.10 \\
\hline
\end{tabular}

${ }^{*} p<.05,{ }^{* *} p<.01$

TABLE 4

BETA, ADJUSTED R SQUARED AND F-STATIC VALUES FOR ALL DIRECT REGRESSIONS BETWEEN CONCEPTS

\begin{tabular}{|l|l|l|l|l|l|l|l|}
\hline & & Dependent & variables & & & & \\
\hline & & Engagement & & & Coaching & Performance & \\
\hline & Beta & Adj. $\mathrm{R}^{2}$ & $\mathrm{~F}$ & & Beta & Adj. $\mathrm{R}^{2}$ & $\mathrm{~F}$ \\
\hline 1. Job Demands & .01 & -.00 & .01 & & $.13^{*}$ & .01 & 6.10 \\
\hline 2. Job Resources & $.20^{* *}$ & .04 & 15.49 & $.13^{* *}$ & .02 & 6.91 \\
\hline 3. Personal Resources & $.63^{* *}$ & .39 & 252.43 & $.59^{* *}$ & .34 & 201.53 \\
\hline 4. Burnout & $-.56^{* *}$ & .31 & 176.10 & $-.32^{* *}$ & .10 & 45.28 \\
\hline 5. Engagement & -- & -- & -- & & $.51^{* *}$ & .26 & 139.05 \\
\hline
\end{tabular}

$* *: p<.01 ; *: p<.05$

The first mediation hypothesis tests the effects of the health impairment process in the JD-R model where the direct effect of job demands is mediated by burnout. First, all direct effects (regression beta's) between the concepts have been calculated and depicted in figure 2 .

FIGURE 2

OVERVIEW OF THE FOUND DIRECT EFFECTS (BETAS), BETWEEN THE CONCEPTS OF THE BURNOUT MEDIATION HYPOTHESIS

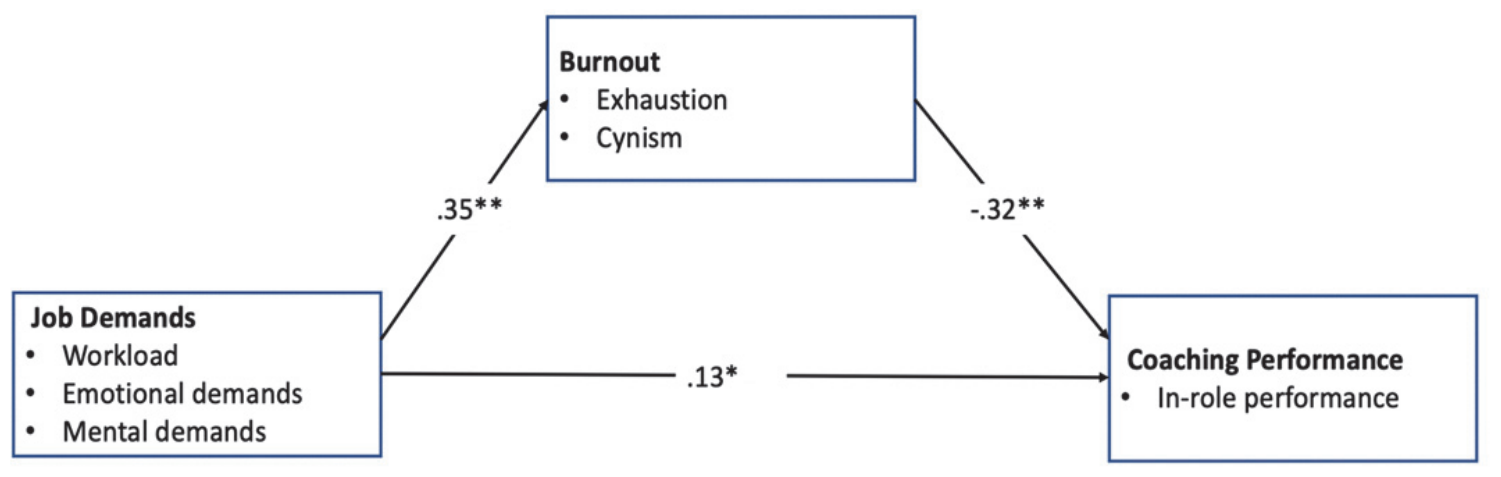

62 Journal of Management Policy and Practice Vol. 20(3) 2019 
Looking at the direct effects between the concepts, it is clear that burnout plays an important role in the relationship between job demands and coaching performance as the direct effect between the two is weaker $($ Beta $=.13)$ than the relationship between job demands and burnout $($ Beta $=.35)$, and the relationship between burnout and coaching performance (Beta $=-.32)$. All the direct effects are significant. The next step is to test whether the effect from the mediator variable, in this case burnout, is significantly different from zero. This test is referred to as the Aroian test (Aroian, 1947) and provides a way to validate mediating effects in data analysis. The outcomes of the Aroian test indicate that burnout is a significant mediator on the effect of job demands on coaching performance $(z=-2.23, \mathrm{SD}=0.01$, $p<.05)$. Next, hierarchical regression analyses where performed to test the extent of the mediating effect of burnout on the relationship between job demands and coaching performance, the results of which are presented in table 5 .

TABLE 5

\section{RESULTS OF THE HIERARCHICAL REGRESSION ANALYSIS TO TEST THE POTENTIAL MEDIATING EFFECT OF BURNOUT ON THE RELATIONSHIP BETWEEN JOB DEMANDS AND COACHING PERFORMANCE}

\begin{tabular}{|l|l|l|l|l|l|l|l|}
\hline Model & & Unstandardized & coefficients & & Standardized & coefficients & \\
\hline & B & Std. Error & Adj. $R^{2}$ & & Beta & Sign. & F \\
\hline & & & & & & & \\
\hline 1 Constant & 3.81 & .14 & & & & & \\
\hline Job Demands & .12 & .05 & & & .13 & .01 & \\
\hline & & & .01 & & & & \\
\hline & & & & & & & \\
\hline Constant & 3.99 & & .13 & & & & \\
\hline Job Demands & .25 & .05 & .17 & & -.42 & .00 & \\
\hline Burnout & -.27 & .03 & & & .00 & 39.45 \\
\hline
\end{tabular}

Dependent variable: Coaching Performance

When looking at model one, the direct effect of job demands on coaching performance is positive $($ Beta $=.13)$ and significant $(p<.05)$. Unexpectedly, the direct effect of job demands on coaching performance increases $($ Beta $=.27)$ and stays significant $(p<.01)$ when burnout is added to the regression model. This is an indication for an interaction effect between job demands and burnout. Since the direct effect of job demands on coaching performance remains significant when burnout is added to the regression model, burnout acts as a partial mediator to the effect of job demands on resources, rejecting hypothesis 2 .

The second mediation hypothesis investigates the mediating role of engagement on the direct effect of job resources on coaching performance. The direct effects have been tested and presented in figure 3 . All the direct effects are significant $(p<.01)$. 
FIGURE 3

OVERVIEW OF THE FOUND DIRECT EFFECTS (BETAS), BETWEEN THE CONCEPTS OF THE ENGAGEMENT MEDIATION HYPOTHESIS

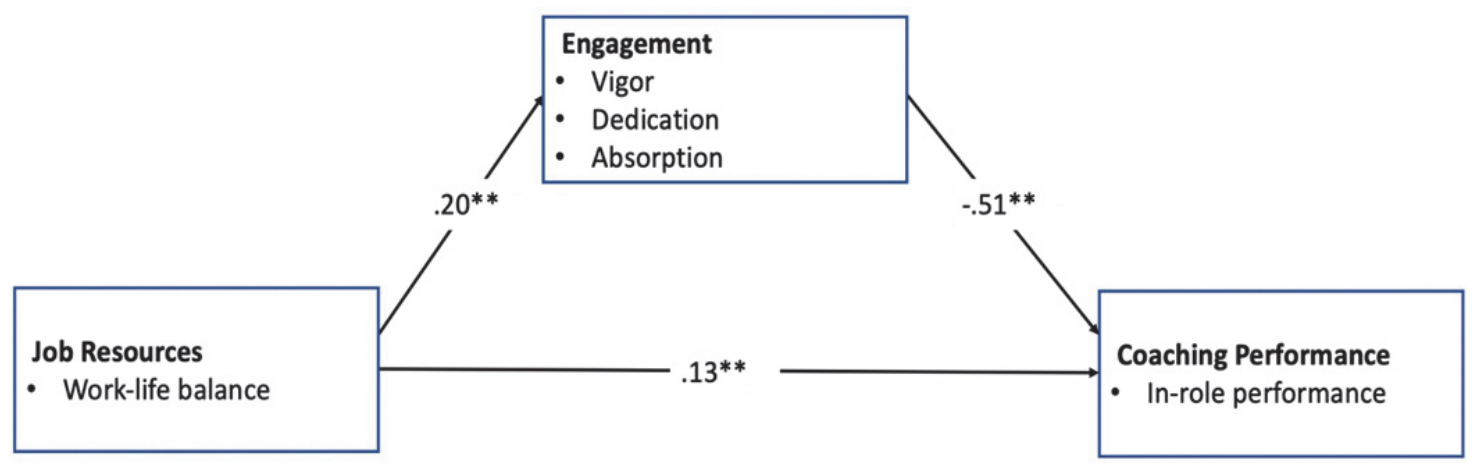

Because all direct effects are found to be significant and positive in the expected direction, the next step is to test the mediation model in hierarchical regression analysis, the results of which are presented in table 6 .

TABLE 6

RESULTS OF THE HIERARCHICAL REGRESSION ANALYSIS TO TEST THE POTENTIAL MEDIATING EFFECT OF ENGAGEMENT ON THE RELATIONSHIP BETWEEN JOB RESOURCES AND COACHING PERFORMANCE

\begin{tabular}{|c|c|c|c|c|c|c|}
\hline Model & & Unstandardized & coefficients & Standardized & coefficients & \\
\hline & B & Std. Error & $\operatorname{Adj} . R^{2}$ & Beta & Sign. & $\mathrm{F}$ \\
\hline 1 Constant & 3.69 & .18 & & & & \\
\hline Job Resources & .11 & .04 & & .13 & .01 & \\
\hline & & & .02 & & & 6.91 \\
\hline 2 Constant & 2.76 & .17 & & & & \\
\hline Job Resources & .03 & .04 & & .03 & .46 & \\
\hline Engagement & .24 & .02 & .26 & .51 & .00 & 69.72 \\
\hline
\end{tabular}

Dependent variable: Coaching Performance

Model one shows that the direct effect of job resources on coaching performance is positive (Beta $=$ $.13)$ and significant $(p<.01)$. When testing the addition of engagement in model two, the direct effect of job resources on coaching performance decreases $($ Beta $=.03)$ and is no longer significant $(p>.05)$. The direct effect of engagement is quite strong $($ Beta $=.51)$. The outcomes of the Aroian test indicate that engagement is a significant mediator on the effect of job resources on coaching performance $(z=2.67$, $\mathrm{SD}=0.01, p<.01)$. In conclusion, engagement fully mediates the direct effect of job resources on coaching performance, accepting hypothesis 4. 


\section{DISCUSSION}

This study adds to the JD-R research body (Demerouti et al. 2001; Schaufeli \& Bakker, 2004) by investigating the relationship between role performance, burnout, engagement, personal resources and the organizational environment and testing these concepts in the context of coaching professionals. Seven hypotheses were formed, each to investigate specific effects within the model to answer the central research question: "To what extent does the organizational environment influence the performance of coaching professionals and to what extent do burnout, engagement and personal resources influence this relationship?" The results indicate that the organizational environment has a direct effect on coaching performance. Burnout, engagement and job resources are indicated as mediators this effect, which is in line with established findings (Bakker et al., 2004; Schaufeli \& Bakker, 2004). The results of the study further indicate that personal resources best predict coaching performance, which is also in line with expectations from earlier research (Bakker et al., 2004; Xanthopoulou et al., 2007). In contrast with earlier research (Xanthopoulou et al., 2007) the results of this study indicate that both job demands and resources have a direct, albeit weak, positive effect on personal resources. This could be explained by the positive effect that was found between mental demands and coaching performance. Job demands were expected to be negatively valued aspects of the job that require energy (Schaufeli \& Bakker, 2004). Mental demands, however, acted differently and showed a positive relationship with both personal resources and coaching performance. One plausible explanation for this can be found in the way the coaches perceive mental demands. It is likely that the coaches feel positively challenged, engaged by mental demands, which makes them perform better. The finding that mental demands seem to act more like a job resource than a job demand is an argument against the categorization of the organizational environment into job demands and resources. Schaufeli and Bakker (2004) confirmed that the antecedents of both burnout and engagement tend to overlap, suggesting using strongly different job demands and resources to be used in studies to benefit the discriminant validity between job demands and resources.

Self-efficacy, stress resilience, dedication, mental demands and emotional demands together explain the most variance in coaching performance. Of the three dimensions of engagement, dedication is indicated to be the best predictor of coaching performance, which is in line with earlier findings (Halbesleben \& Wheeler, 2008; Kodden \& Roelofs, 2019). The results of this study indicate that job resources, personal resources, engagement and coaching performance are highly interrelated. These results confirm the hypothesis set forth by Xanthopoulou et al. (2009b) that through reciprocal interaction, job resources, personal resources and engagement have a positive effect on organizational outcomes, and in this study, coaching performance. The results of this study indicate that the JD-R model can be used to structure and predict the performance of professional coaches. This is important because it allows coaching businesses to optimize the organizational environment to benefit their key value drivers, the professional coaches. This will allow coaching businesses to optimize the return on their investment in their own human capital. This study shows that taking a positive psychology approach to management is likely to encourage coaches to become less burned out and be more engaged to perform.

\section{CONCLUSIONS, LIMITATIONS AND FUTURE RESEARCH DIRECTIONS}

Both burnout and engagement are indicated to have significant direct effects on coaching performance. Burnout in turn is indicated to negatively affect coaching performance and engagement to positively affect coaching performance. Engagement does explain somewhat more variance in coaching performance than burnout. The next logical step when following the JD-R model from right to left is to investigate the organizational environment, which leads to the sub-question: "To what extent do job demands and resources influence burnout and engagement?" Both job demands and job resources have indicated direct effects on burnout and engagement respectively when tested with regression analyses. This underlines the expected effects of the dual process model where job demands lead to burnout and job resources to engagement (Schaufeli \& Bakker, 2004). The results of this study indicate that personal resources stimulate engagement and reduce burnout. Personal resources also indicate to be a valid 
predictor of coaching performance. The insights into the sub-questions can be synthesized to answer the central research question: "To what extent does the organizational environment influence the performance of coaching professionals and to what extent do burnout, engagement and personal resources influence this relationship?" The results indicate that the organizational environment has a direct effect on coaching performance and that burnout, engagement and job resources mediate this effect. Personal resources are the strongest predictor of coaching performance in this study. This leads to the central conclusions that the organizational environment in terms of job demands and resources can directly stimulate and hinder the performance of coaches, depending on how each of the factors in the organizational environment is viewed by the coach. The second and final conclusion is that burnout, engagement and personal resources mediate the direct effects of job demands and resources on coaching performance. The focus therefore lies on optimizing the organizational environment to benefit coaching performance. Several biases that come with self-reported data are known to lead to measurement errors (Podsakoff, MacKenzie, Lee \& Podsakoff, 2003). Common biases that potentially play a role in this study are the desire for respondents to answer consistently; the respondents can feel that they are expected to provide certain answers instead of their true answers. Respondents can hold implicit theories towards the measured concepts that can affect the way respondents complete the questionnaire. Social desirability bias can play a role; respondents might skew their answers towards what would in their eyes to be culturally acceptable and appropriate. The conditions under which the respondents complete the questionnaire is not controlled for, therefore the level of concentration or the amount of distractions while completing the questionnaire could vary per respondent. Selection bias might play a role. The respondents work or have worked for a company that is or has been certified by the certification institute that provided the contact details. This means that this study involved respondents that are associated with companies that care or have cared about being certified on the quality of their services. This type of company might attract specific type of coaching professional. Another factor is the truthfulness of the respondents. The assumption is made that all respondents have completed this questionnaire truthfully as there are no way to truly control this with an online questionnaire. One important observation in the data is that response numbers dropped somewhat when items with "coach" in it, referring to the respondent, were shown. This implies that even though respondents feel they fit the questionnaire criteria of helping others to become employed or helping others with their position in the labor market, they do not call themselves coaches. Another potential bias lies in the fact that the majority of the respondents had received higher education (HBO: 67\%, WO: 27\%, combined: $94 \%$ ), which may have resulted in range restrictions when measuring each of the concepts. In addition, because two of the three measured job resources had to be removed from the study because of missing values, job resources was only measured with one concept. Three or more job resources will better represent job resources in the JD-R model. The cross-sectional nature of this study prevents any causal relations to be indicated. Longitudinal studies can provide insights into the causal nature of relationships between factors. Finally, several limitations around the conceptualization and measurement of job burnout have been recently highlighted (Maslach, 2017; Bianchi et al, 2014; 2019) as well as missing the social support construct in the job-demands resource model that might have a greater contribution to health and well-being outcomes in those involved in helping occupations (cf., HoltLunstad et al, 2015). This study has investigated the JD-R model specifically aimed at performance of professionals in the coaching industry. Future research can improve the JD-R model by investigating the valuation of job demands and resources to gain more specific insights in the effects job demands can have on engagement and the effects job resources may have on burnout. Investigating how job demands and resources are valued will provide better insight into the discriminant validity of both job demands and resources (Schaufeli \& Taris, 2014). In addition, using a longitudinal approach, more specific insights into the potential reverse causation between personal resources, engagement and job resources can be investigated to better identify the interaction between these concepts. 


\section{REFERENCES}

Aroian, L. A. (1947). The probability function of the product of two normally distributed variables. Annals of Mathematical Statistics, 18, 265-271.

Bakker, A. B., Demerouti, E., \& Sanz-Vergel, A. I. (2014). Burnout and work engagement: The JD-R approach. Annual Review of Organizational Psychology and Organizational Behavior, 1(1), 389411.

Bakker, A. B., Tims, M., \& Derks, D. (2012). Proactive personality and job performance: The role of job crafting and work engagement. Human Relations, 65(10), 1359- 1378.

Bakker, A. B., \& Leiter, M. P. (Eds.). (2010). Work engagement: A handbook of essential theory and research. Psychology Press.

Bakker, A. B., Boyd, C. M., Dollard, M., Gillespie, N., Winefield, A. H., \& Stough, C. (2010). The role of personality in the job demands-resources model. Career Development International, 15, 622636.

Bakker, A. B., Hakanen, J. J., Demerouti, E., \& Xanthopoulou, D. (2007). Job resources boost work engagement particularly when job demands are high. Journal of Educational Psychology, 99, 274-284.

Bakker, A.B., Demerouti, E., \& Verbeke, W. (2004). Using the job demands-resources model to predict burnout and performance. Human resource management, 43(1), 83- 104.

Bakker, A. B., Demerouti, E., Taris, T. W., Schaufeli, W. B., \& Schreurs, P. J. (2003). A multigroup analysis of the Job Demands-Resources Model in four home care organizations. International Journal of stress management, 10(1), 16.

Barney, J., Wright, M., \& Ketchen, D. J. (2001). The resource-based view of the firm: Ten years after 1991. Journal of management, 27(6), 625-641.

Bakker, A. B., Schaufeli, W. B., Sixma, H., Bosveld,W., \& Van Dierendonck, D. (2000). Patient demands, lack of reciprocity, and burnout: a five-year longitudinal study among general practitioners. Journal of Organizational Behavior, 21, 425-441

Baumeister, R., \& Leary, M. R. (1995). The need to belong desire for interpersonal attachments as a fundamental human motivation. Psychological Bulletin, 117, 497- 529.

Bianchi, R., Schonfeld, I. S., \& Laurent, E. (2019). Burnout: Moving beyond the status quo. International Journal of Stress Management, 26(1), 36-45.

Bianchi, R., Truchot, D., Laurent, E. Brisson, R. \& Schonfeld, I.S. (2014). Is burnout solely job-related? A critical comment. Scandavian Journal of Psychology.

Blomme, R. J., \& Kodden, B. (2014). Engagement: a new concept in the hospitality industry? The role of management in increasing engagement amongst hospitality workers. In The Routledge Handbook of Hospitality Management (pp. 85-93). Routledge.

Blomme, R. J., \& Kodden, B. (2015). Leadership theories and the concept of work engagement: Creating a conceptual framework for management implications and research. Journal of Management \& Organization, 21(02), 125-144.

Bowerman, B. L., O'Connell, R. T., \& Murphree, E. S. (2011). Business statistics in practice (6th ed.). New York, NY: McGraw-Hill.

Brill, P.L. (1984) The need for an operational definition of burnout. Family and Community Health, 6 , $12-24$.

Buunk, B. P., de Jonge, J., Ybema, J. F., \& de Wolff, C. J. (1998). Psychosocial aspects of occupational stress. In P. J. D. Drenth, H. Thierry, \& C. J. de Wolff (Eds.), Handbook of work and organizational psychology: Vol. 2. Work psychology 145-182. East Sussex, UK: Psychology Press.

Csikszentmihalyi, M. (1975). Play and intrinsic rewards. Journal of humanistic psychology.

Deci, W. L., \& Ryan, R. M. (1985). Intrinsic motivation and self-determination in human behavior. New York: Plenum. 
Demerouti, E., \& Cropanzano, R. (2010). From thought to action: Employee work engagement and job performance. In A. B. Bakker, \& M. P. Leiter (Eds.), Work engagement: A handbook of essential theory and research. New York: Psychology Press.

Demerouti, E., Bakker, A. B., \& Bulters, A. J. (2004). The loss spiral of work pressure, work-home interference and exhaustion: Reciprocal relations in a three-wave study. Journal of Vocational Behavior, 64, 131-149.

Demerouti, E., Bakker, A. B., Nachreiner, F., \& Schaufeli, W. B. (2001). The job demands-resources model of burnout. Journal of Applied psychology, 86(3), 499.

Etzion, D., \& Pines, A. (1986). Sex and culture in burnout and coping among human service professionals: a social psychological perspective. Journal of Cross-Cultural Psychology, 17, 191209.

Etzion, D. (1984). The moderating effect of social support on the relationship of stress and burnout. Journal of Applied Psychology, 69, 615-22.

Garrosa, E., Moreno-Jiménez, B., Rodríguez-Muñoz, A., \& Rodríguez-Carvajal, R. (2011). Role stress and personal resources in nursing: A cross-sectional study of burnout and engagement. International Journal of Nursing Studies, 48(4), 479-489.

González-Romá, V., Schaufeli, W. B., Bakker, A. B., \& Lloret, S. (2006). Burnout and work engagement: Independent factors or opposite poles? Journal of Vocational Behavior, 68(1), 165-174.

Goodman, S. A., \& Svyantek, D. J. (1999). Person-organization fit and contextual performance: Do shared values matter. Journal of Vocational Behavior, 55(2), 254- 275.

Groenland, E. (2014) 'The problem analysis for empirical studies. Int. J. Business and Globalization, $12(3), 249-263$.

Grover, S. \& Furnham, A. (2016). Coaching as a Developmental Intervention in Organisations: A Systematic Review of Its Effectiveness and the Mechanisms Underlying It.

Gruman, J. A., \& Saks, A. M. (2011). Performance management and employee engagement. Human Resource Management Review, 21(2), 123-136.

Hackman, J. R., \& Oldham, G. R. (1980). Work redesign. Reading, MA: Addison Wesley.

Hair, J. F., Black, W. C., Babin, B. J., \& Anderson, R. E. (2010). Multivariate data analysis: A global perspective (7th ed.). Upper Saddle River, NJ: Pearson Prentice Hall.

Hakanen, J.J., Bakker, A.B., \& Schaufeli, W.B. (2006). Burnout and work engagement among teachers. Journal of School Psychology, 43, 495-513.

Halbesleben, J. R. (2010). A meta-analysis of work engagement: Relationships with burnout, demands, resources, and consequences. In Work engagement: A handbook of essential theory and research, $8,102-117$.

Halbesleben, J. R., \& Wheeler, A. R. (2008). The relative roles of engagement and embeddedness in predicting job performance and intention to leave. Work \& Stress, 22(3), 242-256.

Halbesleben, J.R.B, \& Bowler, M. (2007). Emotional Exhaustion and Job Performance: The Mediating Role of Motivation. Journal of Applied Psychology, 92(1), 93-106.

Hallberg, U., \& Schaufeli, W. B. (2006). "Same same" but different? Can work engagement be discriminated from job involvement and organizational commitment? European Psychologist, 11, $119-127$

Hannah, S. T., Avolio, B. J., Luthans, F., \& Harms, P. D. (2008). Leadership efficacy: Review and future directions. The Leadership Quarterly, 19(6), 669-692.

Hobfoll, S.E., Johnson, R.J., Ennis, N., \& Jackson, A.P. (2003). Resource loss, resource gain, and emotional outcomes among inner city women. Journal of Personal and Social Psychology, 84, $632-43$.

Hockey, G. R. J. (1993). Cognitive-energetical control mechanisms in the management of work demands and psychological health, 68. 
Jones, R.J., Woods, S.A \& Guillaume, Y.R. (2015). The effectiveness of workplace coaching: A metaanalysis of learning and performance outcomes from coaching. Journal of Occupational and Organizational Psychology.

Judge T.A., Van Vianen A.E.M., \& De Pater I.E. (2004). Emotional stability, core self- valuations, and job outcomes: a review of the evidence and an agenda for future research. Human Performance, $17,325-46$.

Judge, T. A., Bono, J. E., \& Locke, E. A. (2000). Personality and job satisfaction: The mediating role of job characteristics. Journal of Applied Psychology, 85, 237-249.

Kahn, R.L., \& Byosiere, P. (1992). Stress in organizations. In M.D. Dunnette, \& L.M. Hough (Eds.), Handbook of Industrial and Organizational Psychology. Palo Alto, CA: Consulting Psychologistst Press.

Kant, I., Jansen, N.W.H., Van Amelsvoort, L.G.P.M., Mohren, D.C.L., Swaen, G.M.H (2004). Burn-out in de werkende bevolking. Resultaten van de Maastrichtse Cohort Studie. Gedrag en Organisatie. $17,5-17$.

Karasek Jr, R. A. (1979). Job demands, job decision latitude, and mental strain: Implications for job redesign. Administrative science quarterly, 285-308.

Kodden, B. (2011). Dedication. Breukelen: Nyenrode Business Universiteit.

Kodden, B., \& van Ingen, R. (2019). Knowledge Productivity in the 2020s: Time for a New E/RA A Research Study on the Impact of Organizational Design and Employee Engagement on the Knowledge Productivity of Service Firms. Journal of Applied Business and Economics, 21(4).

Kodden, B., \& Roelofs, J. (2019). Psychological Contract as a Mediator of the Leadership-Turnover Intentions Relationship. Journal of Organizational Psychology, 19(2).

Kožená, L., Frantík, E., \& Horváth, M. (1998). Cardiovascular reaction to job stress in middle-aged train drivers. International journal of behavioral medicine, 5(4), 281-294.

Lai, Y., \& McDowall, A. (2014). A systematic review (SR) of coaching psychology: Focusing on the attributes of effective coaching psychologists. International Coaching Psychology Review, 9(2), 120-136.

Lee, R. T., \& Ashforth, B. E. (1993). A further examination of managerial burnout: Toward an integrated model. Journal of organizational behavior, 14(1), 3-20.

Leiter (Eds.). (n.d.). Work engagement: The handbook of essential theory and research. New York: Psychology Press.

Lewig, K.A., Xanthopoulou, D., Bakker, A.B., Dollard, M.F., \& Metzer, J.C. (2007). Burnout and connectedness among Australian volunteers: A test of the Job Demands-Resources model. Journal of vocational behavior, 71, 429-445.

Llorens, S., Schaufeli, W.B., Bakker, A.B. \& Salanova, M. (2006). Does a positive gain spiral of resources, efficacy beliefs and engagement exist? Computers in Human Behavior, 23, 825-841.

Lorente, L., Salanova, M., Martinez, I., \& Schaufeli, W. B. (2008). Extension of the job demandsresources model in the prediction of burnout and engagement among teachers over time. Psicotema, 20, 354-360.

Luthans, F., \& Youssef, C. M. (2007). Emerging positive organizational behavior. Journal of management, 33(3), 321-349.

Luthans, F., Avey, J. B., Avolio, B. J., Norman, S. M., \& Combs, G. M. (2006). Psychological capital development: toward a micro-intervention. Journal of Organizational Behavior, 27(3), 387-393.

Maslach, C. (2017, June). Finding solutions to the problem of burnout. Consulting Psychology Journal: Practice and Research, 69(2), 143-152.

Maslach, C., \& Leiter, M. P. (2008). Early predictors of job burnout and engagement. Journal of applied psychology, 93(3), 498.

Maslach, C., Schaufeli, W.B. \& Leiter, M.P. (2001) Burnout. Annual Review of Psychology, 52, 397-422.

Maslach, C. (1993). Burnout: A multidimensional perspective.

Maslach, C., \& Jackson, S. E. (1984). Burnout in organizational settings. Applied Social Psychology Annual, 37(5), 133-153. 
Meijman, T. F., \& Mulder, G. (1998). Psychological aspects of workload. Handbook of Work and Organizational Psychology, 2.

Moore, J. E. (2000). Why is this happening? A casual attribution approach to work emotional exhaustion consequences. Academy of Management Review, 25, 335-349.

Norman, G. (2010). Likert scales, levels of measurement and the "laws" of statistics. Advances in health sciences education, 15(5), 625-632.

Osborne, J. W. (2015). What is Rotating in Exploratory Factor Analysis? Practical Assessment, Research \& Evaluation, 20(2), 2.

Podsakoff, P. M., MacKenzie, S. B., Lee, J. Y., \& Podsakoff, N. P. (2003). Common method biases in behavioral research: a critical review of the literature and recommended remedies. Journal of applied psychology, 88(5), 879.

Robert, G., \& Hockey, J. (1997). Compensatory control in the regulation of human performance under stress and high workload: A cognitive-energetical framework. Biological psychology, 45(1), 73 93.

Ross, S. A. (1973). The economic theory of agency: The principal's problem. The American Economic Review, 134-139.

Ryan, R. M., \& Frederick, C. (1997). On energy, personality, and health: Subjective vitality as a dynamic reflection of well-being. Journal of personality, 65(3), 529-565.

Salanova, M., Schaufeli, W. B., Xanthopoulou, D., \& Bakker, A. B. (2010). The gain spiral of resources and work engagement: Sustaining a positive work life. Work engagement: A handbook of essential theory and research, 118-131.

Salanova, M., Agut, S., \& Peiró, J. M. (2005). Linking organizational resources and work engagement to employee performance and customer loyalty: The mediation of service climate. Journal of Applied Psychology, 90, 1217-1227.

Schats, I. (2011). 40.000 Coaches in Nederland, Tijd voor een Shake-out? Tijdschrift voor Coaching, 2, 30-33.

Schaufeli, W. B., \& Taris, T. W. (2014). A critical review of the Job Demands-Resources Model: Implications for improving work and health. In Bridging occupational, organizational and public health, 43-68. Springer Netherlands.

Schaufeli, W. B., Taris, T. W., \& Van Rhenen, W. (2008). Workaholism, burnout and engagement: Three of a kind or three different kinds of employee well-being. Applied Psychology: An International Review, 57, 173-203.

Schaufeli, W. B., Taris, T. W., \& Bakker, A. B. (2006a). Dr Jekyll or Mr Hyde? On the differences between work engagement and workaholism. Research companion to working time and work addiction, 193-217.

Schaufeli, W. B., Bakker, A. B., \& Salanova, M. (2006b). The measurement of work engagement with a short questionnaire a cross-national study. Educational and psychological Measurement, 66(4), 701-716.

Schaufeli, W. B., \& Bakker, A. B. (2004). Job demands, job resources, and their relationship with burnout and engagement: A multi-sample study. Journal of organizational Behavior, 25(3), 293-315.

Schaufeli, W.B., Salanova, M., Gonzalez-Roma, V. \& Bakker, A.B. (2002). The measurement of engagement and burnout: a two-sample confirmatory factor analytic approach. Journal of Happiness Studies, 3, 71-92.

Schaufeli, W. B., Leiter, M. P., Maslach, C., \& Jackson, S. E. (1996). Maslach Burnout InventoryGeneral Survey. In C. Maslach, S. E. Jackson, \& M. P. Leiter (Eds.), The Maslach Burnout Inventory: Test manual, 3, 22-26. Palo Alto, CA: Consulting Psychologists Press.

Scheier, M. F., Carver, C. S., \& Bridges, M. W. (1994). Distinguishing optimism from neuroticism (and trait anxiety, self-mastery, and self-esteem): a reevaluation of the Life Orientation Test. Journal of personality and social psychology, 67(6), 1063.

70 Journal of Management Policy and Practice Vol. 20(3) 2019 
Schroeder, T. (2015). Quality enhancement and assurance in research work via scientific coaching: a theoretical basis for inter-institutional and cross-regional research activities in East and Southeast Asia.

Schwarzer, R., \& Jerusalem, M. (1995). Optimistic self-beliefs as a resource factor in coping with stress. In Extreme stress and communities: Impact and intervention, 159-177. Springer Netherlands.

Seligman, M. E., \& Csikszentmihalyi, M. (2000). Positive psychology: An introduction. American Psychological Association, 55(1), 5.

Sherman, W. S. (2007). Improving organizations by coaching individual development using the resourcebased business strategy. SAM Advanced Management Journal, 72(4), 40.

Shirom, A. (2003). Job-related burnout: A review. In J. C. Quick \& L. E. Tetrick (Eds.), Handbook of occupational health psychology. Washington, DC: American Psychological Association.

Spss, I. (2012). IBM SPSS statistics version 21. Boston, Mass: International Business Machines Corp.

Taris, T. W. (2006). Is there a relationship between burnout and objective performance? A critical review of 16 studies. Work \& Stress, 20(4), 316-334.

Taylor, S.E. (2003). Health Psychology. New York: McGraw-Hill.

Theeboom, T., Beersma, B., \& Van Vianen, A.E.M. (2014). Does coaching work? A meta-analysis on the effects of coaching on individual level outcomes in an organizational context. The Journal of Positive Psychology.

Toppinen-Tanner, S., Kalimo, R., \& Mutanen, P. (2002). The process of burnout in white-collar and bluecollar jobs: eight-year prospective study of exhaustion. Journal of Organizational Behavior, 23(5), 555-570.

Van den Broeck, A., Van Ruysseveldt, J., Smulders, P., \& De Witte, H. (2011). Does intrinsic value orientation strengthen the impact of job resources? A perspective from the job demandsresources model. European Journal of Work and Organizational Psychology, 20, 581-609.

Van Vegchel, N., De Jonge, J., Bosma, H., \& Schaufeli, W. (2005). Reviewing the effort- reward imbalance model: drawing up the balance of 45 empirical studies. Social Science \& Medicine, 60(5), 1117-1131.

Veldhoven, M. J. P. M., \& Meijman, T. F. (1994). Het meten van psychosociale arbeidsbelasting met een vragenlijst: de vragenlijst beleving en beoordeling van de arbeid (VBBA). Nederlands Instituut voor Arbeidsomstandigheden (NIA).

Veldhoven, M. V., Jonge, J. D., Broersen, S., Kompier, M., \& Meijman, T. (2002). Specific relationships between psychosocial job conditions and job-related stress: A three-level analytic approach. Work \& Stress, 16(3), 207-228.

Wagnild, G. M. (1993). Development and Psychometric. Journal of Nursing Measurement, 1(2).

White, R. W. (1959). Motivation reconsidered: the concept of competence. Psychological Review, 66, 297-333.

Wilson, B., \& Laschinger, H. K. S. (1994). Staff Nurse Perception of Job Empowerment and Organizational Commitment: A Test of Ranter's Theory of Structural Power in Organizations. Journal of Nursing Administration, 24(4S), 39-47.

Xanthopoulou, D., Bakker, A. B., Demerouti, E., \& Schaufeli, W. B. (2007). The role of personal resources in the job demands-resources model. International journal of stress management, 14(2), 121.

Xanthopoulou, D., Bakker, A. B., Demerouti, E., \& Schaufeli, W. B. (2009a). Work engagement and financial returns: A diary study on the role of job and personal resources. Journal of Occupational and Organizational Psychology, 82, 183-200.

Xanthopoulou, D., Bakker, A. B., Demerouti, E., \& Schaufeli, W. B. (2009b). Reciprocal relationships between job resources, personal resources, and work engagement. Journal of Vocational behavior, 74(3), 235-244. 